\title{
Can we set a global threshold age to define mature forests?
}

Philip Martin, Martin Jung, Francis Q Brearley, Relena Ribbons, Emily R Lines, Aerin L. Jacob

Globally mature forests appear to be increasing in biomass density. There is disagreement whether these increases are the result of increases in $\mathrm{CO} 2$ concentrations or a legacy effect of previous land-use. Recently, it was suggested that a threshold of 450 years should be used to define mature forests and that many forests increasing in biomass may be younger than this. However, the study making these suggestions failed to account for interactions between forest age and climate. Here we revisit the issue to identify: (1) how climate and forest age control global forest biomass density and (2) whether we can set a threshold age for mature forests. Using data from previously published studies we modelled the impacts of forest age and climate on biomass density using linear mixed effects models. We examined the potential biases in the dataset by comparing how representative it was of global mature forests in terms of its distribution, the climate space it occupied and the ages of the forests used. Biomass density increased with forest age, mean annual temperature and annual precipitation. Importantly the effect of forest age increased with increasing temperature, but the effect of precipitation decreased with increasing temperatures. The dataset was biased towards Northern hemisphere forests in relatively dry, cold climates. The dataset was also clearly biased towards forests $<250$ years of age. Our analysis suggests that there is not a single threshold age for forest maturity. Since climate interacts with forest age to determine biomass density a threshold age at which they reach equilibrium can only be determined locally. We caution against using biomass as the only determinant of forest maturity since this ignores forest biodiversity which often takes longer to recover. Future study of the influence of climate on forest biomass should aim to use the data currently being generated by long-term monitoring networks and satellite based observations. 
1 Can we set a global threshold age to define mature forests?

2 Authors: Philip A. Martin ${ }^{1}$, Martin Jung², Francis Q. Brearley ${ }^{3}$, Relena R. Ribbons ${ }^{4,5}$,

3 Emily R. Lines ${ }^{6}$, Aerin L. Jacob ${ }^{7}$

4 Author associations:

$5 \quad{ }^{1}$ Centre for Conservation Ecology and Environmental Science, School of Applied

6 Sciences, Bournemouth University, Poole, BH12 5BB, UK;

7 phil.martin.research@gmail.com

$8 \quad 2$ School of Life Science, University of Sussex, Brighton, BN1 9RH, UK;

9 m.jung@sussex.ac.uk

$10{ }^{3}$ School of Science and the Environment, Manchester Metropolitan University, Chester

11 Street, Manchester, M1 5GD, UK; f.q.brearley@mmu.ac.uk

${ }^{4}$ School of Environment, Natural Resources and Geography, Bangor University,

13 Gwynedd, LL57 2UW, Bangor, UK; rribbons@gmail.com

$14{ }^{5}$ Department of Geosciences and Natural Resource Management, University of

15 Copenhagen, Rolighedsvej 23, 1958 Fredericksberg, Denmark

${ }^{6}$ School of Geography, Queen Mary University of London, Mile End Road, London E1

17 4NS, UK; e.lines@qmul.ac.uk

7 Department of Geography, University of Victoria, Victoria, BC, V8W 3R4, Canada; aerin.jacob@gmail.com

\section{Corresponding Author}

- Philip A. Martin

- Centre for Conservation Ecology and Environmental Science, School of Applied Sciences, Bournemouth University, Poole, BH12 5BB, UK 


\section{Abstract}

Globally, mature forests appear to be increasing in biomass density (BD). There is disagreement whether these increases are the result of increases in atmospheric $\mathrm{CO}_{2}$ concentrations or a legacy effect of previous land-use. Recently, it was suggested that a threshold of 450 years should be used to define mature forests and that many forests increasing in BD may be younger than this. However, the study making these suggestions failed to account for the interactions between forest age and climate. Here we revisit the issue to identify: (1) how climate and forest age control global forest BD and (2) whether we can set a threshold age for mature forests. Using data from previously published studies we modelled the impacts of forest age and climate on BD using linear mixed effects models. We examined the potential biases in the dataset by comparing how representative it was of global mature forests in terms of its distribution, the climate space it occupied, and the ages of the forests used. BD increased with forest age, mean annual temperature and annual precipitation. Importantly, the effect of forest age increased with increasing temperature, but the effect of precipitation decreased with increasing temperatures. The dataset was biased towards northern hemisphere forests in relatively dry, cold climates. The dataset was also clearly biased towards forests $<250$ years of age. Our analysis suggests that there is not a single threshold age for forest maturity. Since climate interacts with forest age to determine $\mathrm{BD}$, a threshold age at which they reach equilibrium can only be determined locally. We caution against using $\mathrm{BD}$ as the only determinant of forest maturity since this ignores forest biodiversity and tree size structure which may take longer to recover. Future research should address the utility and cost-effectiveness of different methods for determining whether forests should be classified as mature.

\section{Introduction}

Forests play an important role in the global climate system, covering nearly onethird of the earth's terrestrial surface and accounting for over three-quarters of terrestrial gross primary production (Pan et al., 2013). Forests also provide vital habitats for biodiversity and supply a wide-range of ecosystem services upon which humans 
depend, such as climate regulation via carbon storage in tree biomass (Foley et al., 2007). Globally, mature or old-growth forests, here defined as those that have developed the structures and species associated with old primary forest (CBD, 2010), appear to be increasing in biomass density (hereafter referred to as BD) (Pan et al., 2011). Mature tropical forests, in particular, have increased in BD by around $0.5 \mathrm{Mg} \mathrm{C}$ ha $^{-1}$ year $^{-1}$ (Baker et al., 2004; Lewis et al., 2009), though the rate of increase now appears to be slowing (Brienen et al., 2015).

Some researchers have hypothesised that increased $\mathrm{CO}_{2}$ concentrations in the atmosphere, as a result of human activities, have stimulated the growth of trees in mature forests, resulting in increased BD (Lewis et al., 2009). However, other researchers reject these claims, hypothesising that that many mature forests are in fact undergoing secondary succession following 'unseen' disturbances that occurred either hundreds of years ago (Brncic et al., 2007; Muller-Landau, 2009) or as a result of extreme weather such as El Niño events (Wright, 2005). If many supposedly mature forests are recovering from previous human influence, then this may account for observed increases in BD (Wright, 2005). It is thus unclear whether the mature forests in studies that showed increases in BD were actually old enough to achieve a state of relative equilibrium, which can take decades to centuries. In addition, mature forests are commonly used as a reference against which to compare biodiversity in degraded forests or alternative land-uses. If a large proportion of mature forests are actually recovering from disturbances themselves, this may lead to an overestimation of the conservation value of degraded forests. However, until recently, there has been no attempt to determine whether there are methods that could be applied globally to enable forests recovering from disturbances to be distinguished from relatively stable mature forests.

Recently, Liu et al. (2014) attempted to address this issue by (i) assessing how climate and forest age affect forest $\mathrm{BD}$, and (ii) using this analysis to define an age threshold for mature forests. The authors concluded that the BD of mature forest stands was highest in areas with a mean annual temperature of $c .8-10^{\circ} \mathrm{C}$ and mean annual precipitation between 1000 and $2500 \mathrm{~mm}$ (Liu et al., 2014). In addition, the authors further suggested that forest BD increased with stand age, plateauing at approximately 
89

90

450 years of age (Liu et al., 2014). However, given that previous work has shown that climate strongly influences both biomass accumulation (Johnson, Zarin \& Johnson, 2000; Anderson et al., 2006; Anderson-Teixeira et al., 2013) and the maximum BD attainable by a forest (Stegen et al., 2011) it seems unlikely that there is a single global age threshold that can be used to define mature forests. Rather if such thresholds are used, they will need to be defined in areas with relatively homogenous climates where accumulation rates and maximum attainable $\mathrm{BD}$ vary relatively little.

To address these issues we use a subset of the data used by Liu et al. (2014) to revisit the questions:

1. How do climate and forest age control the biomass density of global forests?

2. Can we use this to set an age threshold for mature forests globally? While the analyses we present here use the same data as Liu et al. (2014), we improve on their analyses by considering interactions between precipitation, temperature and estimated forest age. Our work shows that these interactions improve model fit considerably, as well as indicating that establishment of a single age threshold for mature forests is ecologically unrealistic.

\section{Methods}

The data we used for this study were taken from Liu et al. (2014) in which the authors tested global-scale correlations between mature forest carbon stocks (biomass density), stand age and climatic variables using data collected from previous studies. Here we used a subset of these data on aboveground biomass density ( $\mathrm{AGB}, \mathrm{Mg} \mathrm{ha}^{-1}$ ) for sites that had estimates of forest age (years), mean annual precipitation ( $\mathrm{mm}$ ), mean annual temperature $\left({ }^{\circ} \mathrm{C}\right)$ and geographic location (latitude and longitude).

To examine our first question of how forest BD is determined by climate and forest age we used linear mixed effect models (LMMs). First, we tested whether accounting for methodological differences between studies and spatial autocorrelation improved model performance compared to null models. To do this we fitted a model with a dummy random effect and compared the corrected Akaike Information Criteria (AICc) value to our null models, which included study level random effects and a matrix to account for spatial autocorrelation. Using the random effects structure deemed most 
120 parsimonious, we then tested the effects of temperature, precipitation and forest age on

121 AGB by running all possible LMMs that included two way interactions as well as less

122

123

124

125

126

127

128

complex additive models. Forest age was log transformed as increases in AGB with age tend to be non-linear (Martin, Newton \& Bullock, 2013). All explanatory variables were standardised following Schielzeth (2010), by subtracting the mean from each value and dividing by the standard deviation. This method allows easier interpretation of coefficients and improves model convergence. To reduce heteroscedasticity in model residuals we log transformed the response variable. Conditional $R^{2}$ values were calculated using the methods of Nakagawa and Schielzeth (2013).

Models were ranked by $\mathrm{AICc}$ and model averaging performed using all models with a $\triangle \mathrm{AICc} \leq 7$ to produce coefficient estimates (Burnham \& Anderson, 2002; Burnham, Anderson \& Huyvaert, 2010). These coefficient estimates were subsequently used to predict $A G B$ in relation to stand age, precipitation and temperature. Based on our results we then inferred an answer to our second question, relating to age thresholds of forest maturity. Variable importance values were calculated for each coefficient and interaction as recommended by Burnham \& Anderson (2002) by combining the $\mathrm{AICc}$ weight of each model in which the variable was included. Calculating the importance values allows the relative importance of each variable in explaining the relationship to be determined (Burnham \& Anderson, 2002). If interactions between climate and forest age were considered to be relatively important we determined that it was not possible to set a global age threshold by which to define mature forests without considering their local characteristics.

It is important in analyses that combine data from multiple sources to determine whether the data being used show signs of bias that might influence a study's results. One example of such a bias is if data is not representative of an overall population which it seeks to represent (Tuck et al., 2014). In the case of our study, such bias may be caused by an over- or under-representation of particular forest ages, certain climates and particular geographic regions. To test for this we (i) examined the age distribution of forests using histograms; (ii) determined the climate space encompassed by the sites used in this study compared to that occupied by forests globally; (iii) and examined the geographical distribution of study sites. For the comparison of the forest climate space 
151 we binned the data on precipitation into bins of $200 \mathrm{~mm}$ and mean annual temperature

152 into bins of $1^{\circ} \mathrm{C}$. We then used a global grid with a resolution of 0.5 decimal degrees to

153 identify where forest was present based on the globcover 2009 dataset (Bontemps et

154 al., 2011). We determined the mean total precipitation and mean annual temperature in

155 each grid cell where forest was present using WorldClim (Hijmans et al., 2005). We then

156 compared the percentage of our data contained within each temperature and

157 precipitation bin with the percentage area of global forests contained in each bin.

158 All analyses were conducted in R version 3.2.1 (R Development Core Team, 2008) and

159 with models produced using the nIme (Pinheiro et al., 2015) and MuMIn packages

160 (Barton, 2015). All R scripts used for analyses can be found at

161 https://github.com/PhilAMartin/Liu_reanalysis.

162

163

164

165

166

\section{Results}

Our model-averaged results indicated positive relationships between AGB and the logarithm of forest age (slope $=0.24, \mathrm{SE}=0.02$, Importance value=1), mean annual temperature (slope $=0.18, \mathrm{SE}=0.04$, Importance value $=1$ ) and mean annual precipitation (slope=0.32, SE=0.04, Importance value=1). Importantly, the slope related to forest age increased with mean annual temperature and was considered to be relatively important (interaction term $=0.06, \mathrm{SE}=0.02$, Importance value $=0.85$ ). In addition, the positive effect of mean annual precipitation on AGB was reversed at higher temperatures (interaction term $=-0.12, \mathrm{SE}=0.02$, Importance value=1). The interaction term between precipitation and forest age was considered to be less important in characterising forest BD (interaction term $=-0.02, \mathrm{SE}=0.02$, Importance value $=0.34$ ). Models included in the model averaging process had reasonable descriptive power with conditional $R^{2}$ values varying from 0.18 to 0.24 . Predictions using model-averaged coefficients did not show a clear plateauing of AGB at any age (Figure 1), contrary to the findings of Liu et al. (2014). These models also had greater support than the models of Liu et al. (2014), containing only age, precipitation and temperature $(\triangle A I C c=112.41,114.17$ and 139.99 respectively), which also showed poor descriptive power (Conditional $R^{2}=0.03,0.04$ and 0.02 respectively, Table 2 ). 
181 There are clear biases in the dataset we used for this analysis. Tropical and southern

182 hemisphere forests are under-represented, relative to the area they cover (Figure 2a).

183 While the data we used also covered a wide range of climatic conditions, there was a

184 bias towards forests found in relatively cold, dry climates and away from warmer, wetter

185 climates (Figure $2 \mathrm{~b}$ ). The dataset we used was also clearly biased towards younger

186 forests, containing relatively few stands $>250$ years of age (Figure 2c); although we

187 note that the ages of many tropical sites appear to be an uncritical reference to

188 Luyssaert et al. (2007), where the ages of the trees in a range of minimally disturbed

189 tropical forests was reported as being between 100-165 years old.

\section{Discussion}

192 Our results indicate that climate and forest age interact to determine aboveground biomass density in global mature forests. This study is, to our knowledge, the first to quantitatively show this interaction. Previous studies have shown that biomass accumulation rate of regrowing forests depends on precipitation and temperature (Johnson, Zarin \& Johnson, 2000; Anderson et al., 2006; Anderson-Teixeira et al., 2013) and that climate is an important constraint of BD in mature forests (Stegen et al., 2011). We show that forests experiencing higher temperatures accumulated biomass more rapidly, in agreement with previous studies (Anderson-Teixeira et al., 2013). However, our results also suggest that there is little interaction between forest age and annual precipitation. Taken together these results support the findings of Anderson et al. (2006) that, on a global scale, temperature drives differential rates of biomass accumulation. However, reality is likely to be more complex than our results suggest. For example, Stegen et al. (2011) suggested that water deficits resulting from interactions between precipitation and temperature are a primary limiting factor of the $\mathrm{BD}$ that can be attained by mature forests. In contrast to the recent study of Liu et al. (2014), we found that it is not possible to set a threshold age at which forests can be considered mature. Since our results indicated that aboveground BD was best determined by models that included interactions between climate and stand age, any threshold age for mature forests must be determined at a relatively local scale. Accumulation of biomass varies locally with soil 
212 nutrient content and drainage, distance to other forest patches and previous land-use

213 (Norden et al., 2015). In addition, local effects such as priority effects, herbivore density,

214 invasive species, pathogen presence and edge effects can all result in unpredictable

215 successional pathways (Norden et al., 2015). Setting a biome-level threshold age at

216 which forests could be considered mature as Liu et al. (2014) did in part of their paper

217 may provide a compromise between global and local thresholds. However, any such

218 estimates must be explicit about the variation in forest trajectories across a given biome.

\section{The need for better data}

Though our analysis is an improvement on that performed by Liu et al. (2014), we were

222

223

224

225

226

227

228

229

230

231

232

233

234

235

236

237

238

239

240

241

242 limited by the representativeness of the data used. These data comprised few tropical forest sites, were biased towards relatively cold, dry forests and very few forests $>250$ years of age were included in the dataset. The lack of data from tropical forests limits the generality of this analysis meaning that we have little confidence about extrapolating our results to the tropics. This is particularly important as tropical forests store approximately one third of global terrestrial carbon (Dixon et al., 1994) and appear to be increasing in BD (Baker et al., 2004; Lewis et al., 2009). As such, our analysis and that of Liu et al. (2014) can say nothing about whether the recent increases in BD in apparently mature tropical forests may be the result of recovery from past disturbances as Liu et al. (2014) suggested. The relative lack of data for forests $>250$ years of age in our study limits our conclusions, given that forests are often thought to take 100-400 years to reach maturity (Guariguata and Ostertag 2001).

Critically, the setting of any threshold requires accurate aging of forests. This is not a trivial task. In mature forests trees are recruited as other die, creating a complex patchwork of differently aged trees (Chazdon, 2014). As such, defining the age of a forest using the oldest tree (as studies that we used data from did) will likely only be accurate in relatively young forests where tree ages do not differ greatly. However, in mature forests where all pioneer individuals have been replaced, the age of the oldest tree no longer provides a useful determinant of forest age. Thus, the precision of our estimates for younger forest are undoubtedly greater, and more useful, than for older forests. Furthermore, as most tropical trees lack annual growth rings, ${ }^{14} \mathrm{C}$ dating is the 
243 only feasible way to currently age most tropical trees and this is prohibitively expensive

244 in most cases.

\section{Difficulties of defining mature forests}

247

248

249

250

251

252

253

254

255

256

257

258

259

260

261

262

263

264

265

266

267

268

269

270

271

272

273

While, in the future, it may be possible to determine at what age forest BD becomes relatively stable, we advise against using this as a definition of forest maturity for three reasons. Firstly, while carbon storage in the form of BD is important from the perspective of alleviating the impacts of climate change, it tends to recover relatively quickly. In tropical secondary forests, community composition of tree species can take $>150$ years to recover, with BD recovering in approximately 100 years (Martin, Newton \& Bullock, 2013). Thus, while biomass accumulation is important, using it alone to define forest successional stage may lead to forests being classified as mature, when they are still undergoing the latter stages of succession. Incorrect classification of forests as mature based solely on aboveground may mean that when comparisons of biodiversity are made with degraded forests, the conservation value of these degraded forests is overestimated. Secondly, though mature forests can appear to be relatively stable when observed over short time periods or as part of a chronosequence, they never reach equilibrium. Over decadal time scales even apparently mature forests rarely show stable BD (Valencia et al., 2009), and are influenced by changes in climate and changes in local land use. Thirdly, one characteristic of old-growth forests is that they do not contain any individual trees that colonised immediately following allogenic disturbances (Chazdon, 2014). As such, forests that contain remnant cohorts of longlived pioneer species should be considered as late successional rather than old-growth forests (Chazdon, 2014). Thus, examining changes in biomass is likely to be of little use in separating late successional forests such as these from true old-growth.

The results of this study and others clearly show it is challenging to define whether a forest should be classed as mature. Previous studies of forest succession suggest that biomass density could be used along with size structure of tree populations (Coomes et al., 2003; Coomes \& Allen, 2007) and species composition to determine maturity (Chazdon, 2014). For example, work in temperate forests has shown that during succession the diameter distribution of trees become more symmetrical due to 
274 lower recruitment rates under closed canopies (Coomes \& Allen, 2007). Examination of

275 a forest's diameter distribution, and especially how it changes over time, can also help

276 to identify issues relating to recruitment limitation or high mortality of large trees

277 (Ghazoul et al., 2015; Martin et al., 2015). Similarly, the size distribution of forest gaps

278 measured with airborne Lidar can be used to distinguish between mature forests and

279 those that have previously been logged and are now undergoing recovery (Wedeux \&

280 Coomes, 2015; Kent et al., 2015). The presence of species characteristic of old-growth

281 conditions, such as trees tolerant of deep shade, may also aid classification of mature

282 forest. Methods such as those developed by Chazdon et al. (2011) are particularly

283 useful as they allow an objective, statistical method to classify species as generalists,

284 pioneers or old-growth species. Using this method Chazdon et al. (2011) showed old-

285 growth and generalist species increased in abundance while pioneer species

286 abundance decreased during succession in a lowland forest in Costa Rica.

287 Ideally, identification of whether a forest should be classified as mature would

288 encompass all of our suggestions, monitored over a number of years. However,

289 relatively few studies have combined these different methods. Research that identifies

290 the usefulness and cost-effectiveness of different metrics for defining forests as mature

291 would help to improve the baseline against which the world's increasingly degraded

292 forests are compared. 
296

297

298

299

300

301

302

303

304

305

306

307

308

309

310

311

312

313

314

315

316

317

318

319

\section{References}

Anderson KJ., Allen AP., Gillooly JF., Brown JH. 2006. Temperature-dependence of biomass accumulation rates during secondary succession. Ecology letters 9:673682.

Anderson-Teixeira KJ., Miller AD., Mohan JE., Hudiburg TW., Duval BD., DeLucia EH. 2013. Altered dynamics of forest recovery under a changing climate. Global change biology 19:2001-2021.

Baker TR., Phillips OL., Malhi Y., Almeida S., Arroyo L., Di Fiore A., Erwin T., Higuchi N., Killeen TJ., Laurance SG., Laurance WF., Lewis SL., Monteagudo A., Neill DA., Vargas PN., Pitman NCA., Silva JNM., Martínez RV. 2004. Increasing biomass in Amazonian forest plots. Philosophical transactions of the Royal Society of London. Series B, Biological sciences 359:353-365.

Barton K. 2015. MuMIn: multi-model inference.

Bondarev A. 1997. Age distribution patterns in open boreal Dahurican larch forests of Central Siberia. Forest ecology and management 93:205-214.

Bontemps S., Defourny P., Bogaert E., Arino O., Kalogirou V., Perez J. 2011. GLOBCOVER 2009 - Products Description and Validation Report. UCLouvain \& European Space Agency.

Brienen RJW., Phillips OL., Feldpausch TR., Gloor E., Baker TR., Lloyd J., LopezGonzalez G., Monteagudo-Mendoza A., Malhi Y., Lewis SL., Vásquez Martinez R., Alexiades M., Álvarez Dávila E., Alvarez-Loayza P., Andrade A., L E O., AraujoMurakami A., E J M., Arroyo L., Aymard C. GA., Bánki OS., Baraloto C., Barroso J., Bonal D., Boot RGA., Camargo JLC., Castilho CV., Chama V., Chao KJ., Chave J., Comiskey JA., Cornejo Valverde F., da Costa L., de Oliveira EA., Di Fiore A., Erwin 
TL., Fauset S., Forsthofer M., Galbraith DR., Grahame ES., Groot N., Hérault B., Higuchi N., Honorio Coronado EN., Keeling H., Killeen TJ., Laurance WF., Laurance S., Licona J., Magnussen WE., Marimon BS., Marimon-Junior BH., Mendoza C., Neill DA., Nogueira EM., Núñez P., Pallqui Camacho NC., Parada A., Pardo-Molina G., Peacock J., Peña-Claros M., Pickavance GC., Pitman NCA., Poorter L., Prieto A., Quesada CA., Ramírez F., Ramírez-Angulo H., Restrepo Z., Roopsind A., Rudas A., Salomão RP., Schwarz M., Silva N., Silva-Espejo JE., Silveira M., Stropp J., Talbot J., ter Steege H., Teran-Aguilar J., Terborgh J., Thomas-Caesar R., Toledo M., Torello-Raventos M., Umetsu RK., van der Heijden GMF., van der Hout P., Guimarães Vieira IC., Vieira SA., Vilanova E., Vos VA., Zagt RJ. 2015. Long-term decline of the Amazon carbon sink. Nature 519:344-348.

Brncic TM., Willis KJ., Harris DJ., Washington R. 2007. Culture or climate? The relative influences of past processes on the composition of the lowland Congo rainforest. Philosophical transactions of the Royal Society of London. Series B, Biological sciences 362:229-242.

Burnham KP., Anderson DR. 2002. Model selection and multimodel inference: a practical information-theoretic approach. Springer Science \& Business Media.

Burnham KP., Anderson DR., Huyvaert KP. 2010. AIC model selection and multimodel inference in behavioral ecology: some background, observations, and comparisons. Behavioral ecology and sociobiology 65:23-35.

Chang X., Che K., Song C., Wang J., Li B. 1997. Biomass and nutrient element accumulation of Sabina prezewalskii forest community. Journal of Northwest Forestry College 12:23-28. 
343 Chazdon RL., Chao A., Colwell RK., Lin SY., Norden N. 2011. A novel statistical

344 method for classifying habitat generalists and specialists. Ecology.

345 Chazdon RL. 2014. Second growth: The promise of tropical forest regeneration in an

346 age of deforestation. University of Chicago Press.

347 China's Forest Editorial Committee. 1999. China's Forest (Volume 2): Coniferous

$348 \quad$ Forest. Beijing, China : China Forestry Publishing House.

349 Coomes DA., Duncan RP., Allen RB., Truscott J. 2003. Disturbances prevent stem

350 size-density distributions in natural forests from following scaling relationships.

$351 \quad$ Ecology letters.

352 Coomes DA., Allen RB. 2007. Mortality and tree-size distributions in natural mixed-age 353 forests. The Journal of ecology.

354 Dixon RK., Solomon AM., Brown S., Houghton RA., Trexier MC., Wisniewski J. 1994.

355 Carbon pools and flux of global forest ecosystems. Science 263:185-190.

356 Feng ZW., Wang XK., Wu G. 1999. Forest Biomass and Productivity in China. Beijing,

$357 \quad$ China : Science Press.

358 Foley JA., Asner GP., Costa MH., Coe MT., DeFries R., Gibbs HK., Howard EA., Olson

359 S., Patz J., Ramankutty N., Snyder P. 2007. Amazonia revealed: forest degradation

360 and loss of ecosystem goods and services in the Amazon Basin. Frontiers in

361 ecology and the environment 5:25-32.

362 Ghazoul J., Burivalova Z., Garcia-Ulloa J., King LA. 2015. Conceptualizing Forest

363 Degradation. Trends in ecology \& evolution 30:622-632.

364 Hijmans RJ., Cameron SE., Parra JL., Jones PG., Jarvis A. 2005. Very high resolution interpolated climate surfaces for global land areas. International Journal of 
367 Hudiburg T., Law B., Turner DP., Campbell J., Donato D., Duane M. 2009. Carbon

368 dynamics of Oregon and Northern California forests and potential land-based

369 carbon storage. Ecological applications: a publication of the Ecological Society of

$370 \quad$ America 19:163-180.

371 Johnson CM., Zarin DJ., Johnson AH. 2000. Post-Disturbance Aboveground Biomass

372 Accumulation in Global Secondary Forests. Ecology 81:1395-1401.

373

Kajimoto T., Matsuura Y., Osawa A., Abaimov AP., Zyryanova OA., Isaev AP., Yefremov DP., Mori S., Koike T. 2006. Size-mass allometry and biomass allocation of two larch species growing on the continuous permafrost region in Siberia. Forest ecology and management 222:314-325.

Keeton WS., Chernyavskyy M., Gratzer G., Main-Knorn M., Shpylchak M., Bihun Y. 2010. Structural characteristics and aboveground biomass of old-growth spruce-fir stands in the eastern Carpathian mountains, Ukraine. Plant Biosystems - An International Journal Dealing with all Aspects of Plant Biology 144:148-159.

Keith H., Mackey BG., Lindenmayer DB. 2009. Re-evaluation of forest biomass carbon stocks and lessons from the world's most carbon-dense forests. Proceedings of the National Academy of Sciences 106:11635-11640.

Kent R., Lindsell J., Laurin G., Valentini R., Coomes D. 2015. Airborne LiDAR Detects Selectively Logged Tropical Forest Even in an Advanced Stage of Recovery. Remote Sensing 7:8348-8367.

Lewis SL., Lopez-Gonzalez G., Sonké B., Affum-Baffoe K., Baker TR., Ojo LO., Phillips OL., Reitsma JM., White L., Comiskey JA., K M-ND., Ewango CEN., Feldpausch 
TR., Hamilton AC., Gloor M., Hart T., Hladik A., Lloyd J., Lovett JC., Makana J-R., Malhi Y., Mbago FM., Ndangalasi HJ., Peacock J., Peh KS-H., Sheil D., Sunderland T., Swaine MD., Taplin J., Taylor D., Thomas SC., Votere R., Wöll H. 2009. Increasing carbon storage in intact African tropical forests. Nature 457:1003-1006.

Liu Y., Wang Q., Yu G., Zhu X., Zhan X., Guo Q., Yang H., Li S., Hu Z. 2011.

Ecosystems carbon storage and carbon sequestration potential of two main tree species for the Grain for Green Project on China's hilly Loess Plateau. Shengtai Xuebao/Acta Ecologica Sinica 31:4277-4286.

397

398

399

400

401

402

403

404

405

406

407

408

409

410

411

Liu Y., Yu G., Wang Q., Zhang Y. 2014. How temperature, precipitation and stand age control the biomass carbon density of global mature forests. Global ecology and biogeography: a journal of macroecology 23:323-333.

Luo T. 1996. Patterns of net primary productivity for Chinese major forest types and their mathematical models. Beijing, China : Commission for Integrated Survey of Natural Resources, Chinese Academy of Sciences.

Luyssaert S., Inglima I., Jung M., Richardson AD., Reichstein M., Papale D., Piao SL., Schulze E-D., Wingate L., Matteucci G., Aragao L., Aubinet M., Beer C., Bernhofer C., Black KG., Bonal D., Bonnefond J-M., Chambers J., Ciais P., Cook B., Davis KJ., Dolman AJ., Gielen B., Goulden M., Grace J., Granier A., Grelle A., Griffis T., Grünwald T., Guidolotti G., Hanson PJ., Harding R., Hollinger DY., Hutyra LR., Kolari P., Kruijt B., Kutsch W., Lagergren F., Laurila T., Law BE., Le Maire G., Lindroth A., Loustau D., Malhi Y., Mateus J., Migliavacca M., Misson L., Montagnani L., Moncrieff J., Moors E., Munger JW., Nikinmaa E., Ollinger SV., Pita G., Rebmann C., Roupsard O., Saigusa N., Sanz MJ., Seufert G., Sierra C., Smith M- 
412

413

414

415

416

417

418

419

420

421

422

423

424

425

426

427

428

429

430

431

432

433

434

L., Tang J., Valentini R., Vesala T., Janssens IA. 2007. CO2 balance of boreal, temperate, and tropical forests derived from a global database. Global change biology 13:2509-2537.

Ma Z., Peng C., Zhu Q., Chen H., Yu G., Li W., Zhou X., Wang W., Zhang W. 2012. Regional drought-induced reduction in the biomass carbon sink of Canada's boreal forests. Proceedings of the National Academy of Sciences of the United States of America 109:2423-2427.

Martin PA., Newton AC., Cantarello E., Evans P. 2015. Stand dieback and collapse in a temperate forest and its impact on forest structure and biodiversity. Forest ecology and management 358:130-138.

Martin PA., Newton AC., Bullock JM. 2013. Carbon pools recover more quickly than plant biodiversity in tropical secondary forests. Proceedings. Biological sciences / The Royal Society 280:20132236.

Muller-Landau HC. 2009. Carbon cycle: Sink in the African jungle. Nature 457:969-970.

Nakagawa S., Schielzeth H. 2013. A general and simple method for obtaining R2 from generalized linear mixed-effects models. Methods in ecology and evolution / British Ecological Society 4:133-142.

Norden N., Angarita HA., Bongers F., Martínez-Ramos M., Granzow-de la Cerda I., van Breugel M., Lebrija-Trejos E., Meave JA., Vandermeer J., Williamson GB., Finegan B., Mesquita R., Chazdon RL. 2015. Successional dynamics in Neotropical forests are as uncertain as they are predictable. Proceedings of the National Academy of Sciences of the United States of America 112:8013-8018.

Pan Y., Birdsey RA., Fang J., Houghton R., Kauppi PE., Kurz WA., Phillips OL., 
435

436

437

Shvidenko A., Lewis SL., Canadell JG., Ciais P., Jackson RB., Pacala SW., McGuire AD., Piao S., Rautiainen A., Sitch S., Hayes D. 2011. A large and persistent carbon sink in the world's forests. Science 333:988-993.

Pan Y., Birdsey RA., Phillips OL., Jackson RB. 2013. The Structure, Distribution, and Biomass of the World's Forests. Annual review of ecology, evolution, and systematics 44:593-622.

Pinheiro J., Bates D., Saikat D., Sarkar D. 2015. nlme: Linear and Nonlinear Mixed Effects Models.

R Development Core Team. 2008. R: A language and environment for statistical computing. Vienna, Austria: R Foundation for Statistical Computing.

Schielzeth H. 2010. Simple means to improve the interpretability of regression coefficients. Methods in ecology and evolution / British Ecological Society 1:103113.

Stegen JC., Swenson NG., Enquist BJ., White EP., Phillips OL., Jørgensen PM., Weiser MD., Monteagudo Mendoza A., Núñez Vargas P. 2011. Variation in above-ground forest biomass across broad climatic gradients. Global ecology and biogeography: a journal of macroecology 20:744-754.

Tan Z-H., Zhang Y-P., Schaefer D., Yu G-R., Liang N., Song Q-H. 2011. An old-growth subtropical Asian evergreen forest as a large carbon sink. Atmospheric environment 45:1548-1554.

Tuck SL., Winqvist C., Mota F., Ahnström J., Turnbull LA., Bengtsson J. 2014. Land-use intensity and the effects of organic farming on biodiversity: a hierarchical metaanalysis. The Journal of applied ecology 51:746-755. 
458 Valencia R., Condit R., Muller-Landau HC., Hernandez C., Navarrete H. 2009.

459 Dissecting biomass dynamics in a large Amazonian forest plot. Journal of tropical $460 \quad$ ecology 25:473-482.

461 Wedeux B., Coomes DA. 2015. Landscape-scale changes in forest canopy structure 462 across a partially logged tropical peat swamp.

463 Wright SJ. 2005. Tropical forests in a changing environment. Trends in ecology \& 464 evolution 20:553-560.

465 Zhou G., Guangsheng Z., Yuhui W., Yanling J., Zhengyu Y. 2002. Estimating biomass 466 and net primary production from forest inventory data: a case study of China's Larix 467 forests. Forest ecology and management 169:149-157.

468 Zhu JJ., Zeng DH., Kang HZ., Wu XY., Fan ZP. 2005. Decline of Pinus sylvestris var. 469 mongolica Plantations on Sandy Land. Beijing, China : China Forestry Publishing $470 \quad$ House. 


\section{1}

Image of influence of age and climate on forest aboveground biomass

Figure 1 - The relationship between forest age and aboveground biomass for differing climate spaces. Panels represent binned mean annual temperature (rows) and total annual precipitation (columns). Points represent individual sites and solid lines predictions from model-averaged coefficients of models with a $\triangle A I C C \leq 7$. The dark band around predictions represents the $95 \%$ confidence interval of the coefficient, with the lighter band representing the $95 \%$ confidence interval when uncertainty in random effects is taken into account. Bins represent quartiles for precipitation and temperature so that each bin contains a similar number of data points. Please note that the $x$ and $y$ axes are not the same for all panels. 


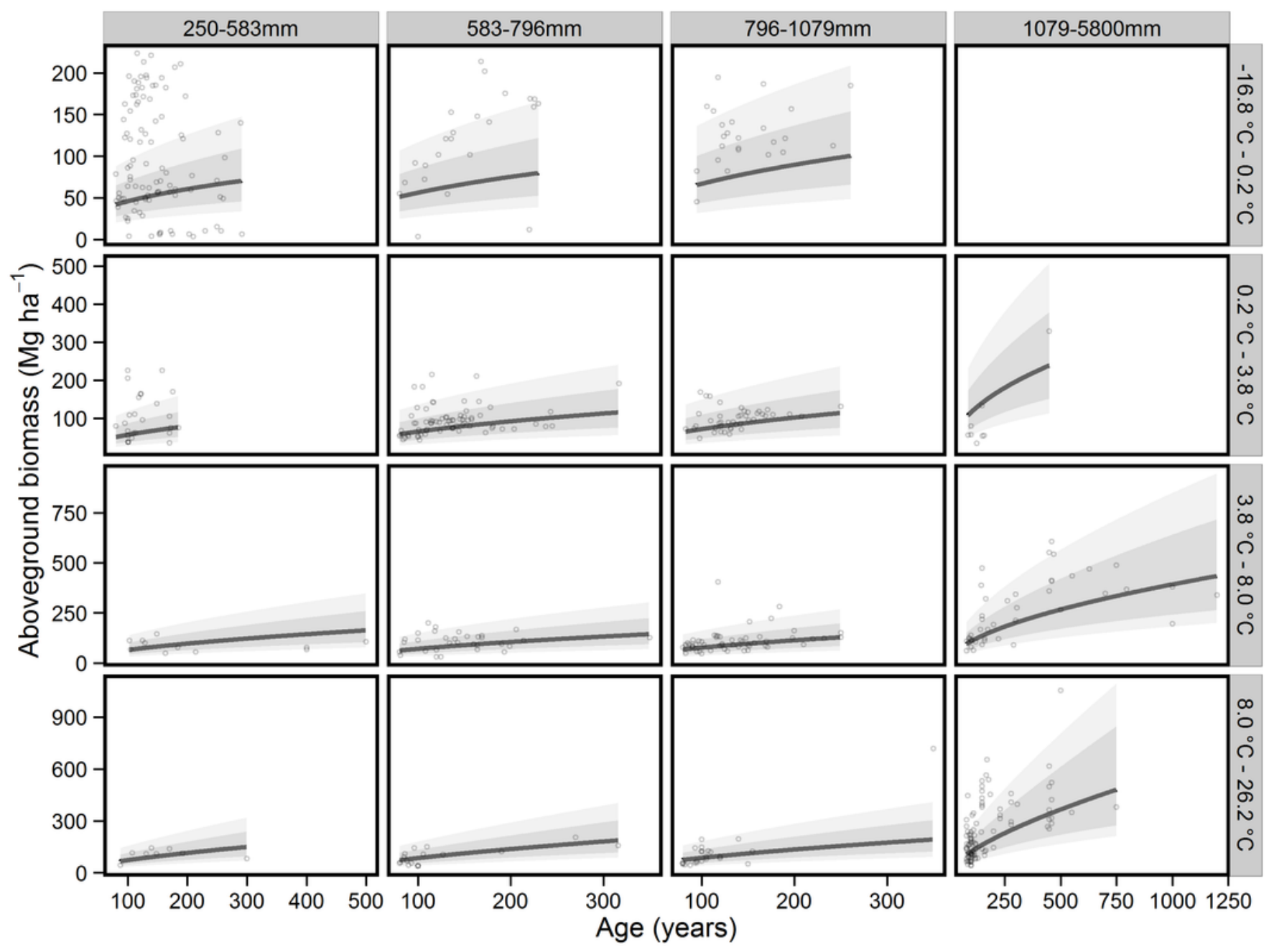




\section{2}

Image showing potential biases in the dataset we used

Figure 2 - Potential biases associated with the dataset we used for this study (a) - Spatial distribution of sites used in this study, showing lack of tropical sites. Green areas represent forest, dots sites used in this study. Dots are partially transparent to give an impression of site density. (b) - Climate space represented by data used in this study and forests globally (climate data from (Hijmans et al., 2005) , forest cover data from (Bontemps et al., 2011) ) . Darker pixel colour indicates greater density of data, indicating a bias towards forests with low precipitation and low mean annual temperature. (c) - Distribution of sites used in this study by site age, showing a bias towards forests $<250$ years old. 

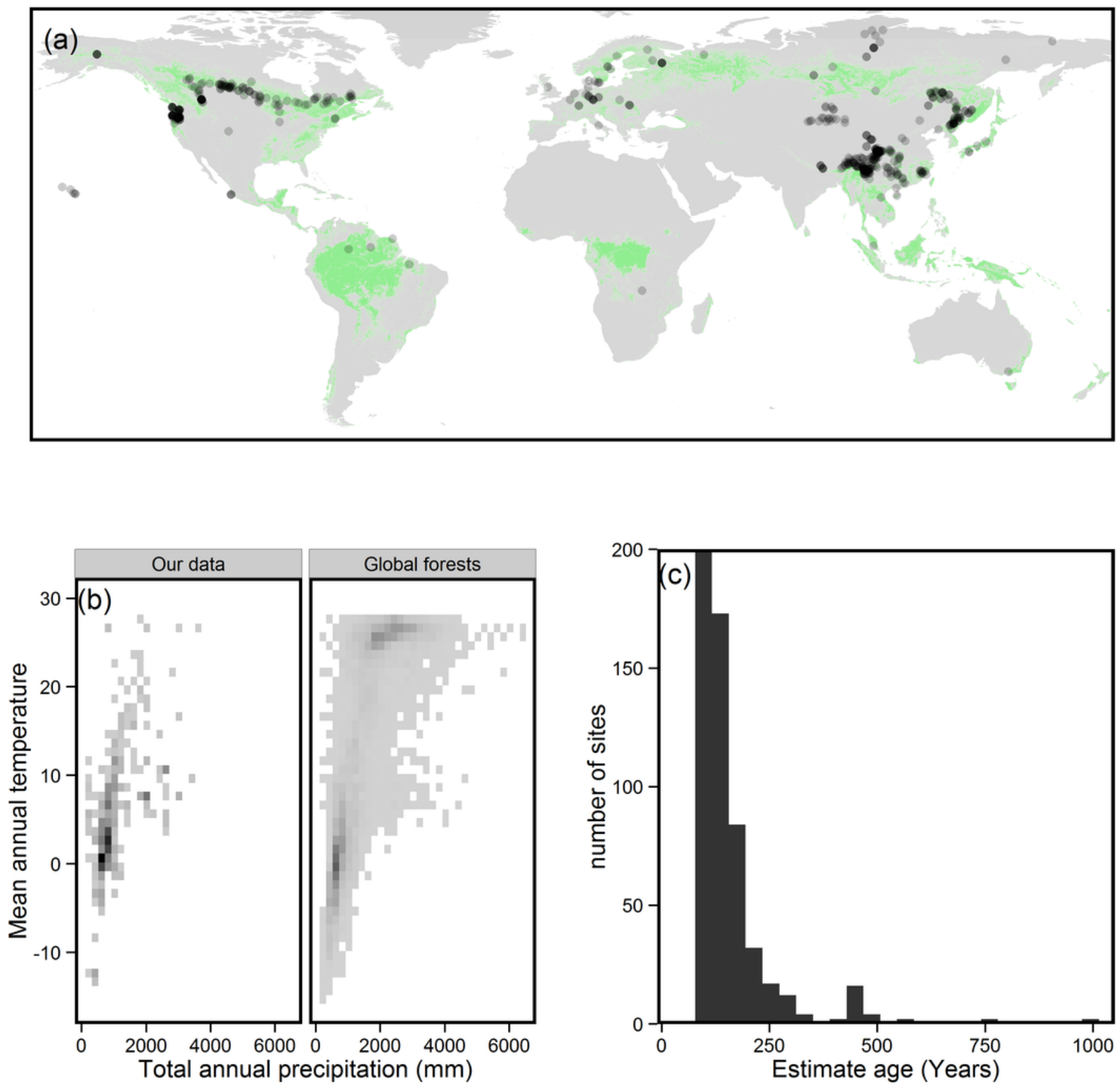
Table $\mathbf{1}$ (on next page)

Table 1

Table 1 - Characteristics of studies used in this paper 
1 Table 1 - Characteristics of studies used in this paper

2

\begin{tabular}{|c|c|c|c|}
\hline Reference & $\begin{array}{l}\text { Mean annual } \\
\text { temperature }\left({ }^{\circ} \mathrm{C}\right)\end{array}$ & $\begin{array}{l}\text { Mean annual } \\
\text { precipitation }(\mathrm{mm})\end{array}$ & $\begin{array}{l}\text { Mean forest age } \\
\text { (years) }\end{array}$ \\
\hline Bondarev, 1997 & -13.3 & 290 & 190 \\
\hline Liu et al., 2011 & 13.6 & 1235 & 87 \\
\hline Chang et al., 1997 & -3.7 & 347 & 204 \\
\hline $\begin{array}{l}\text { China's Forest Editorial } \\
\text { Committee, } 1999\end{array}$ & -1.0 & 470 & 216 \\
\hline Feng, Wang \& Wu, 1999 & 9.0 & 850 & 350 \\
\hline Hudiburg et al., 2009 & 7.8 & 2276 & 423 \\
\hline Kajimoto et al., 2006 & -9.8 & 610 & 158 \\
\hline Keeton et al., 2010 & 7.0 & 800 & 217 \\
\hline $\begin{array}{l}\text { Keith, Mackey \& Lindenmayer, } \\
2009\end{array}$ & 10.7 & 1593 & 500 \\
\hline Liu et al., 2014 & -3.2 & 596 & 163 \\
\hline Luo, 1996 & 5.2 & 889 & 130 \\
\hline Luyssaert et al., 2007 & 7.3 & 1204 & 162 \\
\hline Ma et al., 2012 & -0.1 & 618 & 137 \\
\hline Tan et al., 2011 & 11.3 & 1840 & 300 \\
\hline Zhou et al., 2002 & -4.7 & 446 & 149 \\
\hline Zhu et al., 2005 & -2.0 & 459 & 84 \\
\hline
\end{tabular}

3

4 


\section{Table 2 (on next page)}

Table 2

Table 2 - Candidate mixed effect models for explaining global forest biomass density. $A=$ =Age, $T=$ Temperature, $P=$ Precipitation 
1 Table 2 - Candidate mixed effect models for explaining global forest biomass

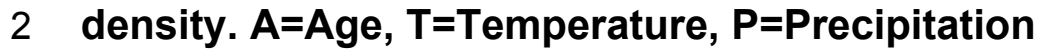

\begin{tabular}{|c|c|c|c|c|c|c|c|}
\hline Formula & $\begin{array}{l}\text { Model } \\
\text { rank }\end{array}$ & df & $\begin{array}{l}\text { log } \\
\text { likelihood }\end{array}$ & $\mathrm{AICc}$ & $\triangle \mathrm{AICc}$ & $\begin{array}{l}\text { AICc } \\
\text { weight }\end{array}$ & Conditional $\mathbf{R}^{2}$ \\
\hline$A+T+P+A^{*} T+T^{*} P$ & 1 & 10 & -305.02 & 630.44 & 0 & 0.56 & 0.25 \\
\hline$A+T+P+A^{*} T+T^{*} P+A^{*} P$ & 2 & 11 & -304.61 & 631.70 & 1.26 & 0.3 & 0.25 \\
\hline$A+T+P+T^{*} P$ & 3 & 9 & -307.74 & 633.81 & 3.37 & 0.1 & 0.21 \\
\hline$A+T+P+T^{*} P$ & 4 & 10 & -307.74 & 635.88 & 5.44 & 0.04 & 0.21 \\
\hline$A+T+P+A^{*} T$ & 5 & 9 & -318.73 & 655.79 & 25.35 & $<0.01$ & 0.15 \\
\hline$A+T+P+A^{*} T+A^{*} P$ & 6 & 10 & -318.43 & 657.25 & 26.82 & $<0.01$ & 0.16 \\
\hline$A+T+P+A^{*} P$ & 7 & 9 & -319.98 & 658.28 & 27.85 & $<0.01$ & 0.12 \\
\hline$A+T+P+A$ & 8 & 8 & -321.03 & 658.32 & 27.88 & $<0.01$ & 0.14 \\
\hline$A+P$ & 9 & 7 & -329.94 & 674.08 & 43.64 & $<0.01$ & 0.10 \\
\hline$A+P+A^{*} P$ & 10 & 8 & -329.74 & 675.73 & 45.3 & $<0.01$ & 0.10 \\
\hline$A+T+A^{*} T$ & 11 & 8 & -333.58 & 683.42 & 52.98 & $<0.01$ & 0.11 \\
\hline$A+T$ & 12 & 7 & -335.71 & 685.63 & 55.19 & $<0.01$ & 0.09 \\
\hline $\mathrm{T}+\mathrm{P}+\mathrm{T}^{*} \mathrm{P}$ & 13 & 8 & -350.23 & 716.72 & 86.28 & $<0.01$ & 0.12 \\
\hline$T+P$ & 14 & 7 & -363.42 & 741.04 & 110.6 & $<0.01$ & 0.04 \\
\hline A & 15 & 6 & -365.35 & 742.84 & 112.41 & $<0.01$ & 0.03 \\
\hline$P$ & 16 & 6 & -366.23 & 744.61 & 114.17 & $<0.01$ & 0.04 \\
\hline $\mathrm{T}$ & 17 & 6 & -379.14 & 770.43 & 139.99 & $<0.01$ & 0.02 \\
\hline Null model & 18 & 5 & -395.95 & 802.01 & 171.57 & $<0.01$ & 0.00 \\
\hline
\end{tabular}

